\title{
Prevalence and Correlates of HIV Testing and Counseling among Sexually Active Adolescents and Young Adults in Harare City, Zimbabwe
}

\author{
Article by Notion Gombe ${ }^{1,2}$, Nicholas Midzi ${ }^{3}$ \\ ${ }^{1}$ Public Health, Texila American University, Guyana, South America \\ ${ }^{2}$ Department of Community Medicine, University of Zimbabwe \\ ${ }^{3}$ Department of Medical Microbiology, University of Zimbabwe \\ E-mail:ntgombe@gmail.com ${ }^{1}$,midzinicholas@gmail.com ${ }^{3}$
}

\begin{abstract}
The HIV prevalence in the Zimbabwean population aged 15-49 years remains high at $15.2 \%$. Most adolescents do not know their HIV status. This is despite knowing a place to get tested. We determined the prevalence and correlates of HIV testing and counseling (HCT) among sexually active adolescents and young adults in Harare City.

We conducted a cross-sectional study among sexually active adolescents and young adults. Data were collected using a pretested self-administered questionnaire. Epi-Info 7 was used to capture and analyze data for frequencies, odds ratios and their corresponding 95\% confidence intervals. Chi-square tests and logistic regression models were used to assess independent correlates of HIV testing. Statistical significance was set at $p<0.01$.

A total of 427 adolescents and young adults were recruited. The majority (56.9\%) were female. The overall prevalence of HIV testing among participants was $56.4 \%$. On multivariate analysis, knowing a facility that offers HIV testing [aOR=5.05; 95\%CI (2.55-10.00)], reporting being involved in a sexual relationship with one's partner [aOR=3.24; 95\%CI (1.67-6.30)], being afraid of a positive result [aOR=0.07;95\%CI(0.01-0.30)] and being male [aOR=0.43;95\%CI(0.23-0.80)]were independent correlates of HCT among adolescents and young adults in Harare City.

Although comparable to other settings in Sub-Saharan Africa, HIV testing among adolescents and young adults in Harare City is still considered very low. Interventions should therefore aim at raising awareness on the importance of HIV testing. In addition city authorities should consider addressing barriers for HCT observed in this study including fear of living with a positive result.
\end{abstract}

Keywords: Adolescents, HIV Testing, Correlates, Prevalence, Harare City.

\section{Introduction}

Globally, there is an estimated 1.2 billion adolescents (10-19 year-olds), constituting $18 \%$ of the world's population (United Nations Children's Fund, 2013). About 2.2 million of these are living with HIV (UNICEF, 2013), and many are unaware of their infection (World Health Organization, 2016). HIV is the second highest cause of mortality after road injury among adolescents and young adults (WHO, 2014). In contrast to reductions in other population groups, estimates suggest that the number of HIV related deaths are on the increase in adolescents (50\% increase) (WHO, 2014). This increase had predominantly occurred in the African region, resulting in AIDS being the leading cause of mortality among adolescents in Africa and second leading cause of death worldwide.

Routine HIV testing for adolescents and adults aged 13-64 years is one of the most important strategies Centers for Disease Control and Prevention (CDC) recommends for reducing the spread of HIV (CDC, 2006). HCT provides an entry point to prevention, care, treatment and support. It contributes to reduction of the stigma and discrimination that surrounds HIV and AIDS. In Zimbabwe, access to knowledge of one's HIV status has mainly been through the client-initiated and provider initiated approaches (Ministry of Health and Child Care, 2014).The government first emphasized on Voluntary 
DOI: $10.21522 /$ TIJPH.2013.06.02.Art021

ISSN: $2520-3134$

Counselling and Testing (VCT) for HIV in the National AIDS Policy of 1999. Since then there has been a remarkable increase in the number of health facilities offering HIV testing and counseling from 395 in 2005 to 1,456 in 2014(United Nations General Assembly, 2014).

In Zimbabwe adolescents continue to be vulnerable to HIV infection. In 2013, it was estimated that a total of 8,366 new HIV infections occurred among children below the age of 15 years, with mother-tochild transmission accounting for up to $90 \%$ of these childhood infections (MOHCC, 2014). In response to the surge in new HIV infections amongst this key population the government of Zimbabwe launched the guidelines for HCT in children and adolescents (MOHCC, 2014). Under these guidelines, a child aged 16 years is considered able to give full consent for HIV testing and counseling. This study sought to determine the prevalence and correlates of HIV testing and counseling among sexually active adolescents and young adults in Harare City, Zimbabwe.

\section{Methods}

A cross-sectional study was conducted in Harare City and the study participants comprised of adolescents and young adults aged 13-24 years. For purposes of this study a resident of Harare City was classified as someone who has lived in Harare for at least three months. All those who fell within the required age range (13-24 years), able to speak and read English and Shona were eligible to participate. Mmen and women who fell outside the 13-24 years age range and visitors to Harare metropolitan province were excluded from participating in the study. Adolescents under age 16 who met the inclusion criteria but whose parents did not provide consent were excluded. Assuming an error risk of 1.96 and a proportion (P), of those tested for HIV (52.2\%) from a previous study conducted by Pelzer et al (2013) in South Africa and a margin of error of $5 \%$, a minimum sample size of 422 was obtained after factoring in $10 \%$ attrition rate.

Data were collected using a pretested self-administered questionnaire designed using the guidance from previous acceptability studies and translated into the local language, Shona. Check codes, and legal values were used to reduce errors of data collection and entry. Data were cleaned for errors and inconsistencies before analysis. Data were analyzed using Epi Info 7 statistical package to generate means, frequencies, proportions, prevalence odds ratios (POR), and their corresponding 95\% confidence intervals (CI). PORs excluding the null value (1) in the $95 \%$ confidence interval were considered statistically significant. Stratified analysis was performed to check for effect modification and to control for confounding. Factors associated with ever being HIV-tested were determined using multivariate logistic regression.

To ensure protection of study participants, permission was sought from Harare City Council institutional review board and the Medical Research Council of Zimbabwe (Approval Number: MRCZ/A/2216). Further, informed written consent was obtained from adolescents aged 16 and older and adolescent assent and parental/guardian consent was obtained from those aged 13-15 years. Consent was obtained after explaining the purpose of the study, and assuring confidentiality. Confidentiality was maintained throughout the study by not including the participants name on the questionnaires. In addition the questionnaire was self-administered owing to the sensitive nature of the questions.

\section{Results}

\section{Sample characteristics}

Socio demographic characteristics of study participants are reported in Table 1. A total of 427 participants were enrolled into this study and females comprised the majority (56.91\%). The majority (82.67) of participants had attained secondary education and the least (4.45\%) were those who had never been to school. Students comprised more than half of the population $(51.76 \%)$ followed by those not employed at $39.58 \%$. High density dwellers formed the majority $(66.04 \%)$ of participants compared to $33.96 \%$ from the low density suburbs. Majority (75.18\%) of participants were single. 
DOI: $10.21522 /$ TIJPH.2013.06.02.Art021

ISSN: $2520-3134$

\section{Prevalence of HIV testing}

In this study the overall prevalence of HIV testing among participants was 56.44\% (241/427). On stratification by sex, prevalence of HIV testing among females was $60 \%$ compared to $51 \%$ for males. Of those that had been tested, $44 \%$ had their most recent test less than 3 months ago. The majority (55.8\%) were tested at council clinics followed by new start centre (17.4\%).

\section{Bivariate correlates of HCT}

Bivariate analysis results show that participants who reported fearing a positive result $[\mathrm{OR}=0.07$; 95\% CI (0.02-0.25)], requiring permission from parents/guardians to test [OR=0.06; 95\% CI (0.01-0.43)], having attained only primary education [OR=0.53; 95\%CI (0.30-0.94)], being aged less than 18 years $[\mathrm{OR}=0.32 ; 95 \mathrm{CI}(0.21-0.49)]$, being worried about confidentiality $[\mathrm{OR}=0.07 ; 95 \% \mathrm{CI}(0.01-0.58)]$ and perceiving oneself not to be at risk of contracting $\mathrm{HIV}[\mathrm{OR}=0.01 ; 95 \% \mathrm{CI}(0.00-0.08)]$ were less likely to be tested for HIV. On the other hand those who reported being involved in a sexual relationship [OR=3.14; 95\% CI (1.77-5.57)], ever being pregnant [OR=5.63; 95\% CI (1.64-19.31)], perceiving oneself to be at risk of contracting HIV [OR=2.36; 95\% CI (1.45-3.84)], having had sexual intercourse in the past year $[\mathrm{OR}=4.44 ; 95 \% \mathrm{CI}(2.60-7.58)]$ among other variables were more likely to be tested for HIV. Participants who knew the location of testing facilities [OR=8.89; 95\% CI (5.30-14.90)] were more likely to be tested for HIV than those who did not know. This was the major determinant for ever being tested in this study population (Table 2).

\section{Multivariate correlates of HCT}

The logistic regression model accounted for 263 cases (Table 3). After controlling for confounding, knowing a facility that offers HIV testing $(\mathrm{aOR}=5.05, \mathrm{p}<0.01)$, reporting being involved in a sexual relationship with one's partner $(\mathrm{aOR}=3.24, \mathrm{p}<0.01)$ being afraid of a positive result $(\mathrm{aOR}=0.07, \mathrm{p}<0.01)$ and being male $(\mathrm{aOR}=0.43, \mathrm{p}=0.008$ ) were independent correlates of HIV testing and counseling among adolescents and young adults in Harare City.

\section{Discussion}

The current study sought to determine the prevalence and correlates of HIV testing and counseling among adolescents and young adults in Harare City, Zimbabwe. This information is critical, as promotion of HCT is the first step to getting medical care and treatment that can improve health, save lives, and prevent the spread of HIV (Bekker \& Hosek, 2015). HCT provides an entry point to prevention, care, treatment and support. It contributes to reduction of the stigma and discrimination that surrounds HIV and AIDS.

The results indicate that $56 \%$ of the study population had ever received an HIV test. Although slightly higher than the proportions reported in similar studies conducted in South Africa (Peltzer \& Matseke, 2013) and Ethiopia (Dirar, Mengiste, Kedir, \& Godana, 2014) such low utilization of VCT in this young key population might pose a challenge to the scale-up of HIV prevention efforts. The results from the South African study indicated that over half (52.2\%) of the youth reported testing for HIV, with more young females testing for HIV compared to their male counterparts (Peltzer \& Matseke, 2013). In Ethiopia the prevalence of HIV testing was slightly higher at 52.8\% (Dirar, Mengiste, Kedir, \& Godana, 2014).

Considering the high HIV prevalence in Zimbabwe, such a low proportion of adolescents and young adults reporting ever having been tested for HIV in this population remains a barrier to early HIV treatment and care among those HIV-infected and this could impact negatively on their survival and result in poor ART response upon initiation.

Females were 1.5 times more likely to be tested compared to their male counterparts. This is supported by other studies. Takarinda et al (2016) in a study on factors associated with ever being HIV tested in Zimbabwe noted that fewer men than women had ever been tested for HIV. Similar trends were noted in a 
DOI: $10.21522 /$ TIJPH.2013.06.02.Art021

ISSN: $2520-3134$

review of 23 out of 29 demographic and health surveys conducted in other sub-Saharan African countries by Staveteig et al (2013). In five countries thus Lesotho, Madagascar, Mozambique, Senegal, and Zimbabwe women are at least 50 percent more likely than men to have ever been tested.

The difference in testing rates between males and females can be attributed to the fact that women have many opportunities for HIV testing for instance during antenatal care and hence this may explain their higher level of HIV testing and generally females compared to males are more responsive to health programs including HIV testing and counseling. In addition it can also be argued that perhaps more females were more likely to be tested since they engage in more sexual relationships at a younger age with 'sugar daddies' than males, hence they could as a precautionary measure get tested to check if their behavior had not resulted in them contracting HIV. In a study done in Kenya and Zambia, for example, prevalence in the 15-19 age group was found to be at least five times higher among the girls (Glynn et al., 2001). This may be due, in part, to the high incidence of consensual, unsafe cross-generational sexual relationships that is, unprotected sex between teenage girls and adult men five or more years their senior (Baltazar, G. M et al. 2001). Men involved in these relationships, are more likely to be infected with HIV than teenage boys since they have been sexually active for longer.

In HIV endemic countries, Zimbabwe included, the World Health Organization (WHO) recommends universal HIV testing for all pregnant women and prompt treatment among HIV-positive women in order to prevent vertical transmission of the virus. Thus, adoption operationalization of longstanding WHO guidelines coupled with national policies may add to the higher prevalence of HIV testing among females than males. In addition traditional masculine roles cast men as risk takers who do not need or seek help or health services (Inungu et al., 2011). Such perceptions delay access to health care including HIV prevention services among men (Varga, 2001).

The study also found out that younger $(<18$ years $)$ participants were significantly less likely to test for HIV than those aged 18years and older. Thus the odds of ever being tested increased with age $\geq 18$ years. Low risk perception reported in this study among younger participants may explain this difference between older and younger participants. It is also important to note that challenges do exist concerning access to HIV testing for persons $<18$ years old as they require parental consent which may explain the low testing uptake for both sexes (Takarinda et al., 2016).

In this study $53.5 \%$ females compared to $36.4 \%$ males reported that they needed permission to go for HIV testing and counseling. In addition, some at-risk youth may not seek medical care due to perceived lack of confidentiality among healthcare providers whereas others may feel inhibited by fear of a positive result or embarrassment associated with seeking reproductive and sexual healthcare. (Swenson et al., 2009; Lichtenstein, 2000; Lindberg, Lewis-Spruill, \& Crownover, 2006).

In this study we conducted both bivariate and multivariate analysis. This allowed us to efficiently determine correlates of HCT and at the same time control for possible confounders that may result in the distortion of the relationships between various exposures and the outcome of interest.

On bivariate analysis several factors were associated with HCT among adolescents and young adults. Those who reported fearing a positive result, parents who would not allow them to test, having attained only primary education, being aged less than 18 years, being worried about confidentiality and perceiving oneself not to be at risk of contracting HIV were less likely to be tested for HIV (Kabiru, Beguy, Crichton, \& Zulu, 2011; Njagi \& Maharaj, 2006). On the other hand those who reported being involved in a sexual relationship, ever being pregnant, perceiving oneself to be at risk of contracting HIV , having had sexual intercourse in the past year were more likely to be tested. Participants who knew the location of testing facilities were more likely to be tested for HIV than those who did not know. This was the major determinant for ever being tested in this study population.

On multivariate analysis, knowing a facility that offers HIV testing, reporting being involved in a sexual relationship with one's partner, being afraid of a positive result and being male were independent correlates of HIV testing in this study. 
DOI: $10.21522 /$ TIJPH.2013.06.02.Art021

ISSN: $2520-3134$

Participants who knew of a facility that offers HIV testing were more likely $(\mathrm{aOR}=5.05)$ to take up an HIV test than those who did not know. The majority (73.54\%) of participants knew of a facility nearby which offers HIV testing and counseling. As expected females comprised the majority (76.95\%) compared to males $(69.02 \%)$. The majority $(79.8 \%)$ of participants who knew of a facility were from the high density suburbs compared to $61.4 \%$ from the low density suburbs. This is consistent with what Leta et al (2012) found out in a cross-sectional study conducted among men in Ethiopia. In that study 53\% of the study participants reported that they knew a place where they could get tested for HIV.

Being involved in a sexual relationship with one's partner was independently associated with HIV testing. Sexually active participants were three times more likely to be tested than those not sexually active. This may be due to self-perceived risk of HIV infection considering that the commonest route for transmitting HIV is through sexual intercourse. A cross sectional study done in Ethiopia, showed that youths who reported having sex with their partners were more likely to be tested (Dirar, Mengiste, Kedir, \& Godana, 2014). This finding is also supported by Leta et al, (2012).

Another significant finding was that those who reported being afraid of a positive result were less likely to be tested for HIV. This was true for both sexes albeit with a marginal difference. This is evident in the 2004 Glasgow study, which assessed the intention of gay men in taking the HIV test. Here, for MSM who had recently engaged in unprotected anal sex, their intention to actually seek testing weakened in the presence of increased fear of a test result that is positive for HIV (Sohn, Cho, \& Kennedy, 2015). This is supported by other studies in the African region (Addis et al., 20103; Strauss, Rhodes, \& George, 2015; Musumari et al., 2016).

This study had some limitations. A key limitation of this study is recall bias and social desirability bias. Data on HIV testing were self-reported by participants without any attempts to validate the report through medical record review. However we tried to minimize the bias through triangulation. In addition there could be other important reasons for these participants not getting tested such as stock-outs of HIV test kits at city clinics which our study did not address. Despite these limitations we are confident that, the survey design and sampling enabled us to draw conclusions which are nationally representative and can be inferred to the general youth population in other urban settings in Zimbabwe and probably beyond.

\section{Conclusion}

Although comparable to other settings in Sub-Saharan Africa, HIV testing among adolescents and young adults in Harare City is still considered very low. This is a significant public health problem as many high-risk individuals are not aware of their serostatus. Independent correlates of HCT among adolescents and young adults in Harare City were, knowing a facility that offers HIV testing, reporting being involved in a sexual relationship with one's partner, being afraid of a positive result and being male. In view of this evidence, Harare City health authorities should urgently come up with innovative strategies to increase the number of adolescents and youth who become aware of their HIV serostatus.

\section{Tables}

Table 1. Socio-demographic characteristics of adolescents and young adults, Harare, Zimbabwe, 2017

\begin{tabular}{|l|l|l|}
\hline Variable & Frequency (n) & $\%$ \\
\hline Sex & 184 & 43.09 \\
\hline Male & 243 & 56.91 \\
Female & 212 & 49.65 \\
Age-group & 177 & 41.45 \\
\hline $13-<18$ & 21 & 4.92 \\
$18-<23$ & 17 & 3.98 \\
$23-<24$ & $24+$ & \\
\hline \multicolumn{2}{|l|}{ Level of education } \\
\hline
\end{tabular}


DOI: $10.21522 /$ TIJPH.2013.06.02.Art021

ISSN: $2520-3134$

\begin{tabular}{|l|l|l|}
\hline $\begin{array}{l}\text { Never been to } \\
\text { school }\end{array}$ & 19 & 4.45 \\
$\begin{array}{l}\text { Primary } \\
\text { Secondary } \\
\text { Tertiary }\end{array}$ & $\begin{array}{l}35 \\
20\end{array}$ & $\begin{array}{l}8.20 \\
82.67 \\
4.68\end{array}$ \\
\hline Occupation & \\
\hline $\begin{array}{l}\text { Not employed } \\
\text { Informally } \\
\text { employed }\end{array}$ & 169 & 39.58 \\
$\begin{array}{l}\text { Formally } \\
\text { employed }\end{array}$ & 19 & 4.45 \\
Student & 18 & 4.77 \\
\hline Area of residence & 221 & 33.96 \\
\hline $\begin{array}{l}\text { Low density } \\
\text { High density }\end{array}$ & 145 & 66.04 \\
\hline Marital status & 282 & 75.18 \\
\hline $\begin{array}{l}\text { Single } \\
\text { Married }\end{array}$ & 321 & 24.82 \\
\hline
\end{tabular}

Table 2 Correlates of HIV testing in adolescents and young adults, harare city, zimbabwe, 2017

\begin{tabular}{|l|l|l|l|l|}
\hline Variable & \multicolumn{2}{|l|}{$\begin{array}{l}\text { Ever been tested } \\
\text { for HIV }\end{array}$} & POR(95\% CI) & p-value \\
\hline \multicolumn{1}{|l|}{ Yes } & No & & \\
\hline $\begin{array}{l}\text { Do you know of any } \\
\text { facility? }\end{array}$ & & & & \\
$\begin{array}{l}\text { Yes } \\
\text { No }\end{array}$ & 218 & 96 & $8.89(5.30-14.90)$ & $<0.001$ \\
\hline $\begin{array}{l}\text { Have you ever been } \\
\text { pregnant? }\end{array}$ & 23 & 90 & & \\
$\begin{array}{l}\text { Yes } \\
\text { No }\end{array}$ & 23 & 3 & $5.63(1.64-19.31)$ & 0.002 \\
\hline $\begin{array}{l}\text { In the last year have } \\
\text { you had sex? }\end{array}$ & 124 & 91 & & \\
$\begin{array}{l}\text { Yes } \\
\text { No }\end{array}$ & 84 & 20 & $4.44(2.60-7.58)$ & $<0.001$ \\
\hline $\begin{array}{l}\text { Residence status } \\
\text { High density }\end{array}$ & 156 & 165 & & \\
$\begin{array}{l}\text { Low density } \\
\text { Are you involved in } \\
\text { sexual relationship } \\
\text { Yes } \\
\text { No }\end{array}$ & 188 & 94 & $3.47(2.28-5.28)$ & $<0.001$ \\
\hline $\begin{array}{l}\text { Do you have a } \\
\text { boyfriend/girlfriend? }\end{array}$ & 53 & 92 & & \\
$\begin{array}{l}\text { Yes } \\
\text { No }\end{array}$ & 88 & 21 & & \\
\hline $\begin{array}{l}\text { Have you ever } \\
\text { discussed about HIV } \\
\text { testing with your } \\
\text { partner? }\end{array}$ & & 66 & $3.14(1.77-5.57)$ & $<0.001$ \\
\hline
\end{tabular}


DOI: $10.21522 /$ TIJPH.2013.06.02.Art021

ISSN: $2520-3134$

\begin{tabular}{|c|c|c|c|c|}
\hline $\begin{array}{l}\text { Yes } \\
\text { No }\end{array}$ & $\begin{array}{l}87 \\
41\end{array}$ & $\begin{array}{l}19 \\
23 \\
\end{array}$ & $2.57(1.26-5.24)$ & 0.009 \\
\hline $\begin{array}{l}\text { Do you feel that you } \\
\text { are at risk of } \\
\text { contracting HIV? } \\
\text { Yes } \\
\text { No }\end{array}$ & $\begin{array}{l}71 \\
170\end{array}$ & $\begin{array}{l}28 \\
158\end{array}$ & $2.36(1.45-3.84)$ & $<0.001$ \\
\hline $\begin{array}{l}\text { Sex } \\
\text { Male } \\
\text { Female }\end{array}$ & $\begin{array}{l}147 \\
94\end{array}$ & $\begin{array}{l}96 \\
90\end{array}$ & $1.47(1.00-2.16)$ & 0.059 \\
\hline $\begin{array}{l}\text { I am not at risk } \\
\text { Yes } \\
\text { No }\end{array}$ & $\begin{array}{l}1 \\
240 \\
\end{array}$ & $\begin{array}{l}53 \\
133 \\
\end{array}$ & $0.01(0.00-0.08)$ & $<0.001$ \\
\hline $\begin{array}{l}\text { My parents will not } \\
\text { allow me to get tested } \\
\text { Yes } \\
\text { No }\end{array}$ & $\begin{array}{l}1 \\
240\end{array}$ & $\begin{array}{l}13 \\
173\end{array}$ & $0.06(0.01-0.43)$ & $<0.001$ \\
\hline $\begin{array}{l}\text { Fear of a positive } \\
\text { result } \\
\text { Yes } \\
\text { No }\end{array}$ & $\begin{array}{l}3 \\
238 \\
\end{array}$ & $\begin{array}{l}27 \\
159 \\
\end{array}$ & $0.07(0.02-0.25)$ & $<0.001$ \\
\hline $\begin{array}{l}\text { I am worried about } \\
\text { confidentiality } \\
\text { Yes } \\
\text { No }\end{array}$ & $\begin{array}{l}1 \\
240 \\
\end{array}$ & $\begin{array}{l}10 \\
176 \\
\end{array}$ & $0.07(0.01-0.58)$ & 0.001 \\
\hline $\begin{array}{l}\text { Age } \\
<18 \\
>18\end{array}$ & $\begin{array}{l}91 \\
150\end{array}$ & $\begin{array}{l}121 \\
65\end{array}$ & $0.33(0.22-0.49)$ & $<0.001$ \\
\hline $\begin{array}{l}\text { Education level } \\
\text { Primary and below } \\
\text { Above primary }\end{array}$ & $\begin{array}{l}23 \\
218 \\
\end{array}$ & $\begin{array}{l}31 \\
155\end{array}$ & $0.53(0.30-0.94)$ & 0.028 \\
\hline
\end{tabular}

Table 3. Multivariable model of predictors of HCT in adolescents and young adults, Harare City, Zimbabwe, 2017

\begin{tabular}{|l|l|l|l|}
\hline Term & $\mathrm{aOR}^{1}$ & $95 \% \mathrm{CI}^{2}$ & $\mathrm{p}$-value \\
\hline $\begin{array}{l}\text { Do you know any facitity that } \\
\text { offers HIV testing? }\end{array}$ & 5.05 & $2.55-10.00$ & $<0.001$ \\
\hline $\begin{array}{l}\text { Are you involved in a sexual } \\
\text { relationship? }\end{array}$ & 3.24 & $1.67-6.30$ & $<0.001$ \\
\hline $\begin{array}{l}\text { Being afraid of a positive } \\
\text { result }\end{array}$ & 0.07 & $0.01-0.30$ & $<0.001$ \\
\hline Sex(Male/Female) & 0.43 & $0.23-0.80$ & 0.008 \\
\hline
\end{tabular}

$1 \mathrm{aOR}$ is adjusted odds ratio

$295 \% \mathrm{Cl}$ is $95 \%$ confidence interval 
DOI: $10.21522 /$ TIJPH.2013.06.02.Art021

ISSN: $2520-3134$

\section{References}

[1].Addis, Z., Yalew, A., Shiferaw, Y., Alemu, A., Birhan, W., Mathewose, B., \& Tachebele, B. (2013). Knowledge, attitude and practice towards voluntary counseling and testing among university students in North West Ethiopia: a cross sectional study. BMC Public Health, 13, 714. https://doi.org/10.1186/1471-2458-13-714.

[2].Baltazar, G. M et al. (2001) AIDS in Kenya: Background, Projections, Impact, Interventions and Policy, eds. 6th Ed, Nairobi, AIDS Control Unit of Ministry Of Health and National AIDS Control Council.

[3].Bekker, L.-G., \& Hosek, S. (2015). HIV and adolescents: focus on young key populations. Journal of the International AIDS Society, 18(2Suppl 1). https://doi.org/10.7448/IAS.18.2.20076.

[4].CDC. Revised Recommendations for HIV Testing of Adults, Adolescents, and Pregnant Women in Health-Care Settings. (2006). Retrieved February 7, 2018, from https://www.cdc.gov/mmwr/preview/mmwrhtml/rr5514a1.htm

[5].Dirar, A., Mengiste, B., Kedir, H., \& Godana, W. (2014). Factors Contributing to Voluntary Counseling and Testing Uptake among Youth in Colleges of Harar, Ethiopia. Science Journal of Public Health, 1(2), 91. https://doi.org/10.11648/j.sjph.20130102.17.

[6].Fact sheet on adolescent health. Geneva: WHO (2014). Retrieved May 18, 2016, from

http://www.unaids.org/en/media/unaids/contentass

[7].Glynn, J. R., Caraël, M., Auvert, B., Kahindo, M., Chege, J., Musonda, R. ... Study Group on the Heterogeneity of HIV Epidemics in African Cities. (2001). Why do young women have a much higher prevalence of HIV than young men? A study in Kisumu, Kenya and Ndola, Zambia. AIDS (London, England), 15 Suppl 4, S51-60.

[8].Inungu, J., Lewis, A., Younis, M. Z., Wood, J., O’Brien, S., \& Verdun, D. (2011). HIV Testing among Adolescents and Youth in the United States: Update from the 2009 Behavioral Risk Factor Surveillance System. The Open AIDS Journal, 5, 80-85. http://doi.org/10.2174/1874613601105010080.

[9].Joint United Nations Programme on HIV/AIDS (UNAIDS). Global AIDS Response Progress. Reporting 2014: Construction of Core Indicators for Monitoring the 2011 UN Political Declaration on HIV and AIDS. Geneva, Switzerland: UNAIDS; 2014.

[10]. Kabiru, C. W., Beguy, D., Crichton, J., \& Zulu, E. M. (2011). HIV/AIDS among youth in urban informal (slum) settlements in Kenya: what are the correlates of and motivations for HIV testing? BMC Public Health, 11, 685. https://doi.org/10.1186/1471-2458-11-685.

[11]. Leta, T. H., Sandøy, I. F., \& Fylkesnes, K. (2012). Factors affecting voluntary HIV counselling and testing among men in Ethiopia: a cross-sectional survey. BMC Public Health, 12, 438. https://doi.org/10.1186/1471-2458$12-438$.

[12]. Lindberg, C., Lewis-Spruill, C., \& Crownover, R. (2006). Barriers to sexual and reproductive health care: urban male adolescents speak out. Issues in Comprehensive Pediatric Nursing, 29(2), 73-88. https://doi.org/10.1080/01460860600677577.

[13]. Lopez-Quintero, C., Shtarkshall, R., \& Neumark, Y. D. (2005). Barriers to HIV-testing among Hispanics in the United States: analysis of the National Health Interview Survey, 2000. AIDS Patient Care and STDs, 19(10), 672683. https://doi.org/10.1089/apc.2005.19.672.

[14]. MOHCC- Zimbabwe National Guidelines for HIV Testing and Counselling in Children and Adolescents (2014). Retrieved January 13, 2018, from https://aidsfree.usaid.gov/sites/default/files/hts_zimbabwe_2014.pdf.

[15]. Musumari, P. M., Tangmunkongvorakul, A., Srithanaviboonchai, K., Yungyuankul, S., Techasrivichien, T., Suguimoto, S. P., ... Chariyalertsak, S. (2016). Prevalence and Correlates of HIV Testing among Young People Enrolled in Non-Formal Education Centers in Urban Chiang Mai, Thailand: A Cross-Sectional Study. PLOS ONE, 11(4), e0153452. https://doi.org/10.1371/journal.pone.0153452.

[16]. Njagi, F., \& Maharaj, P. (2006). Access to voluntary counselling and testing services: Perspectives of young people. South African Review of Sociology, 37(2), 113-127. https://doi.org/10.1080/21528586.2006.10419150.

[17]. Peltzer, K., \& Matseke, G. (2013). Determinants of HIV testing among young people aged 18 - 24 years in South Africa. African Health Sciences, 13(4), 1012-1020. https://doi.org/10.4314/ahs.v13i4.22.

[18]. Strauss, M., Rhodes, B., \& George, G. (2015). A qualitative analysis of the barriers and facilitators of HIV counselling and testing perceived by adolescents in South Africa. BMC Health Services Research, 15(1), 250. https://doi.org/10.1186/s12913-015-0922-0. 
DOI: $10.21522 /$ TIJPH.2013.06.02.Art021

ISSN: $2520-3134$

[19]. Swenson, R. R., Rizzo, C. J., Brown, L. K., Payne, N., DiClemente, R. J., Salazar, L. F., .. Hennessy, M. (2009). Prevalence and Correlates of HIV Testing among Sexually Active African American Adolescents in Four U.S. Cities. Sexually Transmitted Diseases, 36(9), 584-591. https://doi.org/10.1097/OLQ.0b013e3181b4704c.

[20]. Takarinda, K. C., Madyira, L. K., Mhangara, M., Makaza, V., Maphosa-Mutsaka, M., Rusakaniko, S., ... Harries, A. D. (2016). Factors Associated with Ever Being HIV-Tested in Zimbabwe: An Extended Analysis of the Zimbabwe Demographic and Health Survey (2010-2011). PLOS ONE, 11(1), e0147828. https://doi.org/10.1371/journal.pone.0147828.

[21]. UNAIDS Fast track strategy to end AIDS epidemic by 2030, UNAIDS,(2014).Retrieved December 15, 2014, from http://www.unaids.org/en/resources/campaigns/World-AIDS-Day-Report-2014.

[22]. UNAIDS- The gap report (July 2014). Retrived January 13, 2018, from

http://files.unaids.org/en/media/unaids/contentassets/documents/unaidspublication/2014/UNAIDS_Gap_report_en.p df.

[23]. UNGASS- Zimbabwe Global Aids Response Progress Report (2014). Retrieved January 13, 2018, from http://files.unaids.org/en/dataanalysis/knowyourresponse/countryprogressreports/2014countries/ZWE_narrative_rep ort_2014.pdf.

[24]. UNICEF- Analysis of UNAIDS2012 HIV and AIDS Estimates (2013). Retrieved January 13, 2018, from United Nations. United Nations General Assembly (UNGASS) Report: Jan 2006-Dec 2007. United Nations, New York; 2008.

[25]. United Nations General Assembly: country report on the follow up to the declaration of commitment on HIV/AIDS. Reporting period 2006-2007. National Aids Control Program. Pakistan [Internet]. 2008 [cited 18/5/16].:http://aidsdatahub.org/dmdocuments/pakistanUNGASSReport2008.pdf.

[26]. Varga, C. A. (2001). The forgotten fifty per cent: a review of sexual and reproductive health research and programs focused on boys and young men in sub-Saharan Africa. African Journal of Reproductive Health, 5(3), $175-195$.

[27]. WHO. HIV/AIDS fact sheet. (June, 21, 2015). Retrieved July, 21, 2015, from

http://www.who.int/mediacentre/factsheets/fs360/en/ 